\title{
United American Muslims for Peace
}

DOI: http://dx.doi.org/10.5915/23-2-14922

According to various estimates there are seven to ten million Muslims in the USA. These Muslims are represented by various Muslim organizations including Islamic Society of North America, Islamic Circle of North America, American Muslim Mission, National Community under Imam Jamil, American Muslim Council, etc. Besides these, āl-Hamdulillah, there are more than 600 "Masājid" all over the USA. They are communicating with one another at various levels and at various times. However, there was no central organization which could unite them on a broad scale and on one united platform.

Recently, dark clouds started gathering in the Middle East which ultimately culminated in the unfortunate invasion of Kuwait by Iraq. At that critical juncture there was no united Muslim effort in the USA to bring the Muslim "Ummah" together so as to apply political pressure on the USA administration to negotiate a peaceful settlement of the crisis. With the help of Alläh (SWT) and two Muslim brothers, Mr. Naveed Anwar and Mr. Anwar Beig, we formed an organization and called it "United American Muslims for Peace" (UAMP). This organization is unique as there are no portfolios, no president, trustees, or chairman. All Muslims are members. As a first step, we invited Muslim organizations for a telephone conference. Forty-six Muslim leaders from various organizations in the USA and Canada conducted a telephone conference on December 5, 1990, and subsequently met during December 14-16, 1990. More than 69 independent Muslim leaders of thought, university professors, professionals, business and religious leaders from the four corners of the USA and Canada took part. They discussed at length the causes and possible consequences of the Gulf war on the region and Muslim Ummah as a whole. We sent several letters to President Bush and members of the United States Congress. We also sent appeals to the various governments involved and to
President Bush to avert the war, to no avail. We were about to send a delegation to Iraq, Kuwait, Jordan, and Saudi Arabia but the war started before this was accomplished.

We are all aware of the air and the ground war that brought terrible death and destruction. Our organization, "The United American Muslims for Peace" immediately launched a serious campaign to send relief to the war victims. Through contact with the Islamic hospital, and the Islamic Red Crescent in Jordan, we obtained a list of the most needed medical items. An urgent appeal was sent to Muslims, including physicians. Many doctors including women volunteered to go to the Middle East for many weeks to help the war victims. Others donated money and medicines. We have already sent medicines, medical equipment, blankets, and infant milk, (totaling about $\$ 100,000$ ) to civilian war victims through the Islamic Hospital, and the Islamic Red Crescent in Amman, Jordan. The cargo department of Royal Jordan Airline has been very cooperative and we are thankful for that. The members of the Islamic Medical Association have been very generous and forthcoming and we thank them for that.

Insh'allāh, with Allăh's help and your generosity we will continue these efforts. Besides we will continue to bring all Muslims in the USA and Canada on one platform under this umbrella organization. Our future efforts will be directed towards alleviating the miseries of Muslims all over the world. We urgently need your help. Please make your tax deductible donation to your organization, the IMA, or to the Muslim Center of New York, 310 McGuinness Blvd., Greenpoint, NY 11222.

Rasheed Uddin Jaffar, M.D., F.A.C.P. United American Muslims for Peace Phone (516) 868-9694 Fax (516) 379-7627 